\title{
Striated Muscle Cell
}

National Cancer Institute

\section{Source}

National Cancer Institute. Striated Muscle Cell. NCI Thesaurus. Code C33637.

A cylindrical multinucleated cell containing contracting myofibrils, across which run transverse light and dark areas, enclosed in a delicate plasma membrane. 